\title{
Human Capital Development and Higher Education
}

\section{Catherine Laura Mamuli}

Department of Business Administration and Management, School of Business and Economics, Kibabii University, Bungoma, Kenya

\section{Email address:}

Imamuli@kibu.ac.ke

\section{To cite this article:}

Catherine Laura Mamuli. Human Capital Development and Higher Education. European Business \& Management.

Vol. 6, No. 4, 2020, pp. 61-66. doi: 10.11648/j.ebm.20200604.11

Received: May 27, 2020; Accepted: July 7, 2020; Published: July 23, 2020

\begin{abstract}
The paper focuses on the role of higher education as an instrument for improving on human capital development in the country. Emphasis is laid on how Higher Education Institutions (HEIs) in the country can be repositioned for the development of human capital. This paper presents an empirical study that seeks to identify the role of higher education in development of human capital. Content analysis was done from various academic articles world over in relation to the current topic under study. Factors such as government policies, level of technological advancement and enrollment level were discussed. The challenges confronting human capital development in HEIs were highlighted and the strategies for overcoming such challenges deliberated. In the present global environment, characterized by rapid change, intense information flows and increasing competition, emergence of HEIs holds an important place. In today's knowledge based economy, HEIs are playing as centres for human resource development and therefore, aid in the development of the human capital. The paper concludes that higher education should contribute to meeting the social economic needs of the population in terms of relevance of the qualifications offered to the current labour needs. It therefore, recommends that all stakeholders should contribute towards the development and review of the curricula offered in HEIs to conform to the current needs of the Labour Market.
\end{abstract}

Keywords: Higher Education Institutions, Human Capital Development, Human Resource Management, Labour Market

\section{Introduction}

The importance of labour to a nation especially developing economies like Kenya cannot be over-emphasized. More often, the strength of a nation is usually determined by the quantity and quality of her workforce. Physical and mental strength is a necessity for a nation to be great and gain respect and recognition from other countries around the world. Kenya today is regarded as the giant of Africa because of her numeral and physical strength while America remains a world giant due to the quality of her skilled population. The fact that a nation is endowed numerically does not necessarily mean that such a nation will be more developed than others. According to Olaseni and Alade [17] "qualitative education is a major determinant of the stock of human capital. It has proved to be the vehicle for national transformation in human history and no nation ever rises above her investment in education". Physical strength is therefore not a yardstick for development; rather the quality of knowledge acquired through education is important for development to take place. Without quality education, physical strength will be more of a liability than an asset. On his part, Gyang [10] stated that "the growth of tangible capital stock of a nation depends to a considerable degree on human capital development." Therefore, for labour to be relevant to the needs of the society, there is need to continually expose the citizens to training and education so as to allow them contribute meaningfully to development in the various sectors of the economy.

Human capital plays an important role in the development of enterprises and organizations. Human Capital represents the human factor of an organization. It is the accumulation of intellect, qualifications and competence that make up the identity of an organization. Human elements of the organization are those who can learn, invent, and provide a creative impulse, which when adequately directed can ensure the longevity of the organization. The concept "human capital" was established for the first time by T. W. Schulz in 1961 [18], who developed it. In 1981, he wrote: "all human capacities are considered to be congenital or acquired. Human capital refer to qualities which are valuable and can be increased due to the right investment in it". The idea of the investment into the human capital was for the first time 
brought forward in 1776 by A. Smith, who in his work "An inquiry into the nature and causes of the wealth of nations" claimed that the differences between the level of person's education and vocational education reflect the differences in the expenditures necessary to acquire such qualification. Therefore, income from investments into qualification can be fully compared with the income from investments into the physical capital. However, these comparisons are not complete. Companies own a physical capital and not its employees (except slavery society). The value of human capital increases together with the growth of education level, therefore the situation of higher education professionals in the labour market reveals the efficiency of human capital application.

A number of researchers have suggested that the local human capital level has external effects on others nearby, with much of this literature focusing on the external effects of average education levels on productivity and wages. Moretti [14] offers support for the existence of human capital externalities by showing that the local level of human capital is positively correlated with wages even after controlling for individual worker characteristics. However, because workers are mobile, the external effects of human capital on wages will not be the end of the story. Higher productivity in an area will attract new workers and cause the area to grow in population [5, 20, 24, 6]. Glaeser and Beary [7] and Waldorf [22] also suggest that the existing stock of human capital is especially important in attracting educated in-migrants. Furthermore, as new workers move in, they compete with existing residents for housing and bid up housing prices [19, 3]. Shapiro [19] suggests that the local human capital level increases the implicit value of an area's consumption amenities; i.e., the stock of human capital makes an area a more desirable place to live and increases the quality of life. Shapiro [19] estimates that 40 percent of the growth effects of human capital are due to increased quality of life.

Because the local human capital stock appears to make a place better in so many ways, it is paramount to understand why places differ in aggregate human capital levels. One of the most important determinants of the local human capital level is the presence of colleges and universities in the area, and many of the most highly educated areas are home to major state universities [23]. HEIs increase the local human capital stock in at least two ways: 1) they increase access to higher education for local residents and make it more likely that local high school graduates will pursue post-secondary education $[2,1]$; they bring in students from outside the area seeking an education and some of these student in-migrants end up staying in the area after their education is complete [1, 12, 10, 9, 11]. Winters [24] suggests that most of the differential in-migration to high human capital cities is due to students moving to pursue higher education and that most of the growth of so-called "smart cities" is due to recent student in-migrants staying in an area after finishing their education. These students stay in the area because it gives them greater utility than other areas. Importantly, some students might stay in the area where they moved for higher education because it offers a high quality of life. Colleges and universities, therefore, affect their surrounding areas in several important ways.

The term 'higher education' as the name implies literarily refer to that class of education which is among the apex in the educational system of a country. It is the level of education which supersedes all others in the educational hierarchy of a nation. It means that an institution can only form part of the higher education system when it is empowered to produce individuals and certification that is of top priority in the nation's educational system. Higher education is sometimes used interchangeably with the term 'tertiary education' in most educational literatures. Both concepts have always been used to refer to the highest educational level in the country. According to the National Policy on Education (2004), tertiary education comprises of education after secondary school such as universities, colleges of education, polytechnics, and other institutions awarding corresponding courses. Any educational system therefore which comes after the secondary level of education is generally referred to as higher education or tertiary education.

Human resource is a term that is used in most organization to also mean human capital; this is because it is an indispensable resource that is needed to achieve productivity in any organization. Human resource vis-à-vis human capital should be properly managed such that it can be of importance in the future. On his part, Yunus [24] suggested that in order to effectively manage any public institution, there is the need to build a quality group of highly qualified, able and motivated human resources. It is this group of professional individuals that form the human capital in an organization. Their efforts also contribute immensely to the success recorded in the organization. Human capital on the other hand refers to the set of skills and abilities which an employee employs in the organization to get work done. It is a collection of all the new ideas and knowledge which an employee acquires while working which helps to increase onthe-job efficiency and effectiveness. It is therefore imperative that in order for an employee to continuously become relevant in the work environment, he or she must continue to develop new methods of doing work. It is these individuals with the needed expertise to work in an organization and contribute to its growth and development that are referred to human resource or human capital. This paper intends to emphasize the importance and contribution of HEIs in meeting the need of a country's Human Capital and therefore economic development.

\section{Factors That Influence Human Capital Development}

A country's future lies in its people. That is why Kenya, like all other countries, must solve its current human development crisis if it has to achieve meaningful growth and development. The essence of human capital development is 
to train workers to become relevant in their place of work for individual and organizational relevance. However, the development of human capital in various sectors of the economy is usually influenced by one or more of the following factors.

Government Policies: The policies of government either at the national or local government level plays a significant role in determining the options and opportunities available for workers to develop their abilities at work. UNCTAD [21] suggested that the extent to which transnational corporations upgrade their technology and skill base depends on the interaction of host-country government policies. In the same way, government policies determines to a great extent the type and level of skills and technical knowledge acquired by the citizens. The establishment of the right atmosphere through appropriate government policies is needed for the development of human capital.

Level of Globalization: Another factor that influences human capital development is the level of globalization. The amount of rapport between citizens and other advanced countries also provide an opportunity for an enhanced human capital development. Globalization assists in the transfer of new and efficient knowledge for individuals within and outside the country.

Level of Competition: The level of competition in the various industries within the country also determines the level of human capital development. Competition in the business environment encourages research; and research result to the development of new knowledge. It is therefore important to note that the height of competition in the various sectors of the economy will contribute to the improvement of the value of human capital within the society.

Technological Advancement: Since the inception of the 21 st century, technology has become a very important tool for meeting human needs. Similarly, with the instruction of the World Wide Web (www), the transfer of knowledge has become easier and more obtainable. However, the unavailability of internet facilities and other technological gadgets has militated against the ability of individuals to develop. Technological change as one of the factors that help to develop the economic relevance of human capital. The volume of information and idea gotten through modern technology helps to increase the relevance of human capital.

Religious and Socio-Cultural Demand: Religious, social and cultural demands also influence human capital development. Religion, culture and social beliefs usually determine willingness and access to the various opportunities utilized by individuals for their development. The culture of people as well as their religious inclination will either encourage or repel them from improving on their human capital.

\subsection{Challenges Confronting Human Capital Development in Higher Education Institutions in Kenya}

Despite the position of Higher Education Institutions in Kenya as the most important instrument for the development of human capital in the country, very little progress has been recorded. Some of the factors that have limited the ability of HEIs in contributing to the development of human capital in the country are as follows:

Mismanagement: One of the challenges that is ravaging most sectors of the Kenyan economy is that of mismanagement. Most countries with plenty of natural resources are usually less developed economically than others due to the mismanagement of resources. Human, material and financial resources available in HEIs are used for other purposes aside that of human capital development. Sometimes, resources available in HEIs are used for selfish interest or misappropriated. This trend has negatively affected the move for the development of human development.

Poverty: Poverty remains one of the biggest problems. Poverty is the inability of a person to carry out the basic necessities of life. This includes the inability of a person to acquire enough money required to acquire formal education. When such important programmes cannot be achieved, most of the citizens will remain irrelevant in a changing environment. Most students in the school system are so poor that they cannot afford a good meal. As such, the ability to acquire textbooks, computers and other learning materials becomes a mirage.

Inadequate Infrastructures: Any person familiar with Kenya will agree that among the challenges facing the economy is ineffective institutions and dilapidated infrastructure (bad roads, erratic power supply, limited access to potable water and basic healthcare, and ineffective regulatory agencies, among others. All of these facilities are important in the self-development of students. When the appropriate facilities are provided, it will create an enabling environment for students to on self-development. These infrastructure include computer laboratories, workshops and well equipped libraries.

Inadequate Funding: Fund is a very important resource that is needed for the procurement of basic resources needed for developing human capital. Funding is needed for the purchase of all that is required to acquire those human and material resources that are needed to develop the status of other human resources. The inadequacy or unavailability of fund will forestall the growth and development of human resources in various HEIs in the country. When funds are unavailable, it will be difficult for most HEIs in the country to carry out plans, projects and programmes that will enhance students and community development.

Low Level of Individual Interest: Individual interest in developing their abilities plays a significant role in determining the level of human capital development in the country. The willingness of students in acquiring quality education will contribute to the development of their relevance. However, when students are unwilling to change, it will result to a slow or total absence of development of the quality and quantity of human capital within the country. Students in the nation's HEIs need to develop a passion for self-development before change can occur. 


\subsection{Strategies to Overcome the Problem of Human Capital Development in Higher Education Institutions in Kenya}

The creation of an enabling environment for Higher Education Institutions to thrive in the country is highly instrumental for the development of human capital in the country. It is therefore important that the challenges limiting HEIs from contributing to the development of human capital in the country should be addressed. This can be achieved through the following strategies:

Development of Appropriate Information and Communication Technology (ICT) Facilities:

The use of ICT in improving the quality of service delivery in the various sectors of the economy is gaining increasing attention. ICT serves as a device which assists in growing output and refining service delivery. It is therefore paramount that suitable ICT facilities be provided for the training of students and teachers for effective human capital development. Given the revolution in technology and the changes at the workplace, universities in Kenya urgently need internal changes and innovations in terms of structure, curricula, teaching methods and redeployment of resources in the production of critical skills. While in the past university professors have always determined the content to be taught, there is need to involve the learners and other stakeholders in designing education programs as suggested by Lovelock and Rothschild [13]. The institutions must learn to respond to market signals and design programs that respond to industry and society needs [15]. These changes will allow institutions of higher learning in Kenya to allocate their scarce resources to what is needed in the economy in contrast to what is mistakenly considered to reflect economic growth.

Review of Curriculum: Comparison of human capital of our children to the skills required by the jobs of the twentyfirst century global economy. However, in order for the skills and abilities of students to be developed, the curriculum of most of the HEIs in the country need to be reviewed to meet contemporary economic demands. This will help in enhancing the relevance of students in the 21 st century. The HEIs in Kenya under emphasize science, technology and engineering programs due to the enormous cost that must be incurred while pursuing science-based education programs [16]. State universities are unable to offer adequate remuneration and research opportunities that would encourage greater commitment by professors and lecturers. In addition, the institutions are poorly equipped to handle science and technical subjects. In some institutions, equipment, laboratories and other physical assets are outdated. It is obvious that graduates of these outdated technologies cannot be expected to add value to the economy's production system.

On the Job Training: The need for constant training among employees in any formal organization cannot be overemphasized. Developmental programmes and activities play an important role in making employees more effective in the work environment. On-the-job training is one of the avenues through which the expertise of workers can be improved upon. Seminars, conferences, workshops and other training programmes need to be provided for academic staff to improve their quality. A student can hardly rise above the competence of the teacher; it is therefore necessary that lecturers in HEIs be exposed to on the job training to acquire modern teaching techniques. Higher education institutions should encourage lifelong learning for those working in both private and public sectors of the economy since technology changes with time. This will allow workers to acquire the state of-the-art skills and knowledge needed for economic growth. Universities in Kenya should also address the issue of the mismatch of skills that are currently being provided and the skills needed at the workplace. It is a waste of resources and disinvestment in human capital when an excess supply of university graduates find their knowledge and skills irrelevant at the workplace. Thus, majority of Kenyan University graduates have remained unemployed and/or underemployed and must be re-trained to fit in the labor market.

Job Enrichment: The work environment should be equipped with modern and important facilities and equipment that will allow staff and students to go on knowledge search. HEIs in the country should be provided with the necessary human and material resources that will assist in the development of all educational stakeholders within the environment of the institution.

Organizational Restructuring: The structural arrangement of an organization can contribute to the success or failure of the organization. When people and activities are merged based on areas of strength, it will result into increased efficiency. The various faculties and departments in the school should be properly structured in such a way that new staff can learn from other experts in the faculty or department. Such an arrangement will assist in the improvement of the quality of service provided by the various staff. Also, it will assist in improving the skills and abilities of all lecturers. This will make them better-off than when they were initially employed. It will also help to improve the quality of their students.

\subsection{Contribution of Higher Education Institutions to Human Capital Development in in Kenya}

The importance of HEIs in developing quality manpower in the country cannot be over-emphasized. HEIs can contribute to the development of human capital in one or more of the following ways:

Empowering Students Attitude: An area of behavioral change is the social development of people. Building a good attitude is very crucial for a healthy social development. HEIs play major roles in the production students who are responsible both in character and learning therefore, they should more than before take up the responsibility of reshaping the behavior of students towards the development of the society.

Quality Research in Relevant Areas: research is another area where the HEIs contribute to the advancement of the 
society. It is therefore important that more research efforts should be developed by HEIs in the country. This will contribute towards the development of new goods and services that will contribute towards the intellectual development of the society.

Community Development Services: Another area where HEIs can contribute towards the building of human capital development is in the area of community development services. It is needful that frequent orientation should be given to the host community to enlighten and educate them on new findings that are important for their environment. Such knowledge will help to empower the community on how to carry out individual and societal development.

Production of Quality Manpower: One of the objectives of HEIs as stated in the National Policy on Education (2004) is the development of quality manpower. Similarly, the quality of employees developed from the various institutions will also contribute to the society by transferring their knowledge to the other members of the society. It is therefore clear that the quality of graduates from the nation's HEIs will to a greater extent determine the literacy level of the entire society.

Philanthropic Activities: HEIs in the country can also donate goods or services to individuals and institutions for self-empowerment. Areas of needs may be identified by HEIs in the country and necessary contributions made towards the alleviation of such problems. This will assist in the reduction of the level of dependence and incapability of individuals within the society.

\section{Conclusion}

The development of quality human resource is strategic to the development of the entire nation. No nation can rise above the quality of its work force. As such, all HEIs in the country need to work hand-in-hand to contribute towards human capital development in the country. The relevance of quality human capital development cuts across the various sectors of the economy. It is therefore necessary that for the nation to acquire all round growth and development, the development of human capital must be given the desired attention.

\section{Recommendations}

The following are recommended in order to contribute towards the development of quality human capital development in the country:

1. Higher Education Institutions should concentrate on providing informal and functional education, which are less time consuming, less costly and more related to manpower requirements than is a formal educational system.

2. Priorities need to be established for various forms of education and training through frequent manpower surveys and planning. This will enable planners to meet the set targets of the required manpower. Kenya must realize that unless the right kind of education and training is provided, setting overall educational targets will have little meaning.

3. Work competencies and motivations that are favorable to economic growth must be taught. Since effective use of physical capital depends on human capital, priority must be given to growth in the quality of human resources.

4. Adequate finance should be provided for the various HEIs in the country. This will improve on the ability of the various schools to procure basic resources needed for developing quality manpower in the country.

5. Government should ensure to create appropriate laws and policies at all levels which will provide an enabling environment for all HEIs in the country to improve the quality of human capital.

6. Basic infrastructures and amenities should be provided by both the government and other private individuals. This will help to create an appropriate environment for individual's self-development in the country.

7. Adequate rapport should be established between HEIs in the country and other developed economies. This will assist in the transfer of quality knowledge and information that will assist in the development of human resource that can meet with contemporary demand.

\section{References}

[1] Blackwell, M., Cobb, S., Weinberg, D., 2002. The economic impact of educational institutions: Issues and methodology. Economic Development Quarterly 16, 88-95.

[2] Card, D., 1995. Using geographic variation in college proximity to estimate the return to schooling. In: Christofides, L., Swideinsky, R., Grant, E. K. (Eds.), Aspects of Labour Market Behaviour: Essays in Honor of John Vanderkamp. University of Toronto Press, Toronto, pp. 201-222.

[3] Dalmazzo, A., de Blasio, G., 2007a. Production and consumption externalities of human capital: An empirical study for Italy. Journal of Population Economics 20, 359-382.

[4] Dalmazzo, A., de Blasio, G., 2007b. Social Returns to Education in italian local labor markets. Annals of Regional Science 41, 51-69.

[5] Glaeser, E. L., Saiz, A., 2004. The rise of the skilled city. Brookings-Wharton Papers on Urban Affairs, 47-94.

[6] Glaeser, E. L., Scheinkman, J., Shleifer, A., 1995. Economic growth in a cross-section of cities. Journal of Monetary Economics 36, 117-143.

[7] Groen, J. A., 2004. The effect of college location on migration of college-educated labor. Journal of Econometrics 121, 125142 .

[8] Groen, J. A., White, M. J., 2004. In-state versus out-of-state students: The divergence of interest between public universities and state governments. Journal of Public Economics 88, 1793-1814. 
[9] Hickman, D. C., 2009. The effects of higher education policy on the location decision of individuals: Evidence from Florida's Bright Futures Scholarship Program. Regional Science and Urban Economics 39, 553-562.

[10] Huffman, D., Quigley, J. M., 2002. The role of the university in attracting high tech entrepreneurship: A Silicon Valley tale. Annals of Regional Science 36, 403-419.

[11] Lovelock, C. H. \& M. L Rothschild. (1980). Uses, abuses and misuses of marketing in higher education. In Marketing in College Admissions a broadening of perspectives (pp. 31- 69). New York: college Entrance Examination Board.

[12] Moretti, E., 2004a. Human capital externalities in cities. In: Henderson, J. V., Thisse, J. F. (Eds.), Handbook of Regional and Urban Economics, Vol. 4. Elsevier, Amsterdam, pp. 22432291.

[13] Nafukho, F. M. (2004). The market model of financing state universities in Kenya: Some innovative lessons. In P. T. Zeleza $\&$ A. Olukoshi (Eds.), African Universities in the Twenty First Century. (pp. 126-139) Pretoria: University of South Africa Press.

[14] Nafukho, F. M. \& Burnett, F. M. (2002). College choice: The state of marketing and effective student recruitment strategies. In T. M. Egan \& S. A. Lynham (Eds.), Conference Proceedings of the Academy of Human Resource Development (pp. 788-795). Bowling Green, OH: Academy of Human Resource Development.

[15] Nelson W. Wawire \& Fredrick M. Nafukho (2006), Investment in Human Capital through Institutions of Higher Education for the Revival of Kenya's Economy'. ERIC Number ED 492815.

[16] Ngware, M. W. \& Nafukho, F. M. (2002). Determinants of supply of technical training opportunities for human capital development in Kenya. In T. M. Egan \& S. A. Lynham (Eds.), Conference Proceedings of the Academy of Human Resource Development (pp. 893 - 899). Bowling Green, OH: Academy of Human Resource Development.

[17] Olaseni, M. \& Alade, W. (2012). Vision 20: 2020 and the Challenges of Infrastructural Development in Nigeria: Journal of Sustainable Development. 5 (2); 63-76.

[18] Schultz, T. W. (1962) "Investment in human capital in poor countries". In Zook P. D. (Ed) Foreign trade and human capital, 3-12.

[19] Shapiro, J. M., 2006. Smart cities: Quality of life, productivity, and the growth effects of human capital. Review of Economics and Statistics 88, 324-335.

[20] Simon, C. J., 1998. Human capital and metropolitan employment growth. Journal of Urban Economics 43, 223-243.

[21] UNCTAD (2000). The Competitiveness Challenge: Transnational Corporations and Industrial Restructuring in Developing Countries. Geneva: UNCTAD.

[22] Waldorf, B. S., 2009. Is human capital accumulation a selfpropelling process? Comparing educational attainment levels of movers and stayers. Annals of Regional Science 43, 323344 .

[23] Winters, J. V., 2009. Wages and prices: Are workers fully compensated for cost of living differences? Regional Science and Urban Economics 39, 632-643.

[24] Yunus, A. J. M. (n. d.). Human Capital Development and Performance Management. Retrieved from http://www.unpan1.un.org/intradoc/groups/public/documents/. 